\title{
DIE VERHOUDING VAN OU EN NUWE TESTAMENT
}

L. Floor

\section{Inleiding}

Wie 'n ondersoek wil instel na die verhouding tussen die Ou Testament en die Nuwe Testament betree 'n studieveld wat so breed is dat 'n mens dit onmoontlik in sy geheel kan oorsien.

By kruispunte in die kerkgeskiedenis kom telkens hierdie verhouding ter sprake.

Die volgende vrae is herhaaldelik gestel:

Wat is die intrinsieke waarde van die Ou Testament (Hasel: 1972,15 e.v.)?

Hoe funksioneer die Ou Testament in die Nuwe Testament (Noordergraaf: 1976, 21)?

Is die gebruik van Ou-Testamentiese gedeeltes deur Jesus en die apostels vir ons normatief (Labuschagne: 1973, 118 e.v.)?

Op die vraag na die intrinsieke waarde van die Ou Testament gee die nuwe Testament ons 'n duidelike antwoord.

Die Ou Testament word dikwels in die Nuwe Testament aangehaal. In die Nuwe Testament vind ons verwysings na alle boeke van die Ou Testament met uitsondering van Hooglied, Prediker en Ester. Dit is opvallend dat in die Joodse tradisie hierdie drie boeke lank omstrede was en dat hulle eers op 'n baie laat stadium in die kanon van die Ou Testament opgeneem is (Den Heyer: 1982, 20, 21).

Die Ou Testament was vir ons Here Jesus Christus, vir die apostels en vir die eerste Christelike gemeente die gesaghebbende Woord van God. Die Nuwe Testament gee 'n helder en ondubbelsinnige getuienis van hierdie opvatting.

Aanvanklik was daar in die siening op die Ou Testament geen verskil tussen die Joodse sinagoge en die Christelike gemeente nie. Sowel Jode as Christene, rabbyne en apostels het die Ou Testament as die gesaghebbende Woord van God aanvaar. Die verskil tussen kerk en sinagoge het nie gelê in die Skrifgesag nie, maar in die Skrifgebruik. Die Jode het die Ou Testament anders gelees as die Christene. Die Christene uit die Jode het geglo dat Jesus van Nasaret die Messias van Israel en die Seun van God is. Wanneer Jesus inderdaad die verwagte Messias van Israel is dan het die Ou-Testamentiese profesie in Hom sy vervulling gevind. Waar die Christen-Jood in die Ou-Testamentiese profesie 'n duidelike heenwysing na die messiasskap van Jesus gelees het, daar het die Jood op grond van sy uitleg van presies dieselfde Skrifgedeelte dit ten stelligste ontken. 'n Tiperende voorbeeld is die verklaring van Jesaja 53 in die Christelike en in die Joodse tradisie.

'n Vergelyking van die resultate van Paulus se eksegese van die Ou Testament met die rabbynse Skrifverklaring bring ons tot 'n verrassende ontdekking. Paulus en die rabbyne is nie alleen besig om dieselfde boeke nl. die van die Ou Testament te eksegetiseer nie, hulle maak ook gebruik van dieselfde metode van Skrifuitleg. Hoewel die apostel in baie opsigte dieselfde metode van Skrif- 
verklaring gebruik as die rabbyne (die s.g. midrash-metode) en as die manne van die Qumran-gemeenskap (die s.g. pesjer-metode), kom hulle tog tot 'n volkome ander vertolking van die Ou Testament Paulus verkondig uit die Ou Testament dat Jesus die Christus is (Hand. 9:22) en dat Hy die Seun van God is (Hand. 9:20).

Met 'n gelyke metode as Paulus kom die rabbyne tot 'n Torahsentriese verklaring van die Ou Testament, terwyl Paulus die Ou Testament Christosentries verklaar (Helberg: 1976, 20).

Vir Paulus is die Ou Testament nie in die eerste plek wet, gebod nie, maar primêr is die Ou Testament vir hom belofte, prefigurasie van die verlossingswerk wat met die koms van Christus plaas gevind het (Moody Smith: 1972, 16).

Paulus se Christologiese vertolking van die $\mathrm{Ou}$ Testament is geen vrug van wetenskaplike eksegese nie, maar berus op 'n geloofsbeslissing en sy geloof rus op die selfopenbaring van Jesus Christus (Floor: 1979, 56). Ons kan hier van Paulus leer dat vir elke eksegeet en prediker die persoonlike geloof in Jesus Christus van allesbeheersende betekenis is. Jy kan 'n kundige eksegeet wees en 'n bekwame vakman met 'n omvattende kennis van taal, kultuur, struktuur en opbou van 'n teks, sonder geloof in Jesus Christus sal die beste eksegetiese metode en die vakkundige hantering van hermeneutiese reëls en die mees indrukwekkende struktuuranalise 'n mens nie bring tot die regte verstaan van die Ou Testament nie. Nadat die Nuwe Testament as gelykwaardig en gesaghebbend naas die Ou Testament ontstaan het, het al spoedig die verhouding van die twee Testamente problematies geword. Bekend is die opvatting van Marcion wat die Ou Testament radikaal verwerp het, omdat daar volgens hom 'n absolute antitese tussen die Ou Verbond en die Nuwe Verbond is (Quispel: 1959, 573). Aangesien dit onmoontlik is om uit die geskiedenis van die eksegese aan te toon hoe in die loop van die tye die verhouding tussen die twee Testamente gesien en prakties toegepas is, moet ons beperk tot 'n paar hoofmomente naamlik uit die tyd van die Reformasie en die 20 ste eeu.

In die tyd van die Hervorming sien ons hoedat Calvyn en die aanhangers van die Doperse Beweging met dieselfde Bybel besig is. Beide partye aanvaar die Bybel as die Woord van God. Tog verskil die eksegetiese resultate van Calvyn hemelsbreed van die van sy Doperse teenstanders. Dieselfde Bybel word verskillend verklaar. Die probleem lê nie op die terrein van die Skrifgesag nie, maar op die gebied van die Skrifgebruik. Gevolg is dat Calvyn met heeltemal ander verklarings kom oor die doop, die kerk, die eed, die owerheid en die heiliging as die Doperse Beweging.

Wanneer ons die resultate van Skrifverklaring van Calvyn vergelyk met die van sy teenstanders dan blyk dit dat die verskil vernaamlik bepaal word deur 'n verskillende siening op die verhouding Ou Testament en Nuwe Testament.

In die 20 ste eeu sien ons presies dieselfde verskynsel. Met die opkoms en verbreiding van die Pinksterbeweging en later die Pentekostalisme en die Charismatiese Beweging het die vraag na die legitimiteit van die kinderdoop, die wese van die kerk, die heiliging 
van die lewe, die werk van die Heilige Gees in die hart weer volop in diskussie gekom.

In die hernude stryd in verband met die kinderdoop byvoorbeeld is die wyse waarop die Skrifgegewens gehanteer word van die allergrootste belang. Hier kan nie met 'n verwysing na 'n paar insidentele tekste volstaan word nie. Die vraagstuk van die eenheid van God se handele in Ou en Nuwe Verbond kom hier ter sprake. Gaan ons by 'n beroep op die Bybel uit van 'n teenstelling tussen $\mathrm{Ou}$ en Nuwe Testament of handhaaf ons die openbaringseenheid van die Heilige Skrif (Koopmans: 1939, 228)?

Ten diepste gaan dit in die verhouding tussen $\mathrm{Ou}$ en Nuwe Testament oor die struktuur van die evangelie. Kan ons sê dat die struktuur van die evangelie 'n verbondsstruktuur is of moet ons uitgaan van die individualiteit van die geloof? Daar waar die klem val op 'n diep-gewortelde individualisme in die geloofsbelewing en waar teologies 'n spiritualistiese teenstelling tussen natuur en genade gemaak word en wanneer dit ook nog gepaard gaan met 'n gebrekkige hermeneutiek en 'n biblisistiese hantering van die Skrif sonder enige besef van die historiese karakter daarvan dan word die kontinuïteit tussen die Ou Testament en die Nuwe Testament gemaklik prys gegee en alle nadruk op die persoonlike geloofservaring gelê (vgl. Jonker, 1981: 219). Ons moet wel oppas dat ons nie uit reaksie teen 'n oewerlose subjektivisme in 'n koue, objektiewe verstandsgodsdiens beland nie. Die regte siening op die verhouding van Ou en Nuwe Testament sal ons van eensydighede of na die of na die ander kant toe bewaar.

\section{Calvyn en die Doperse Beweging}

Calvyn moes op twee fronte sy stryd voer. Teenoor die RoomsKatolieke kerk met sy sterk Ou-Testamenties gekleurde erediens het Calvyn vanuit die Nuwe Testament God se heil in Christus verkondig en verdedig.

Teenoor die Doperse Beweging het Calvyn met krag die waarde en betekenis van die Ou Testament aangetoon.

Ons vind by die Doperse Beweging ' $n$ eensydige oriëntering op die Nuwe Testament. Die Ou Testament word as minderwaandig beskou. Daar is alles te aards en te liggaamlik. God se heil vertoon in die Ou Testment soveel stoflike, aardse trekke dat dit nie as die volle heil beskou kan word nie. In hul dualistiese benadering waarin die geestelike teenoor en bo die stoflike geplaas word, het die Doperse Beweging die Ou Testament as minderwaardig en verganklik teenoor die Nuwe Testament geplaas (Graafland, 1978: $23,24)$.

Eerlikheidshalwe moet vermeld word dat nie alle leiers van die Doperse Beweging hulle eensydig op die Nuwe Testament georiënteer het nie. Bernhard Rothmann met wie Bucer 'n briefwisseling gevoer het, het die Ou Testament van die grootste betekenis geag. Hy was van oordeel dat die Pentateuch alleen al vir 'n christen voldoende is (Stupperich, 1970: 18 e.v.) Die dualistiese dwaalleer van die Doperse Beweging stem baie ooreen met die dwaalleer van die gnostiek waarteen die apostels reeds moes optree (Quispel, 1972). 
Teenoor die gnostiese, dualistiese dwaalleer van die Doperse Beweging wys Calvyn op die groot betekenis en die blywende waarde van die Ou Testament. In die tweede boek van sy Institusie wy hy drie hoofstukke aan hierdie onderwerp (cap. 9-11). Hy handel agtereenvolgens oor die plek van Christus in die Ou Testament (cap. 9), die gelykheid tussen die $\mathrm{Ou}$ en die Nuwe Testament (cap. 10) en die onderskeid tussen Ou en Nuwe Testament (cap. 11).

Calvyn se gedagtes oor hierdie onderwerp is deur H. H. Wolf in 'n uitstekende proefskrif weergegee en georden onder die titel: Die Einheit des Bundes, das Verhältnis von Altem und Neuem Testament bei Calvin, 1958. Die titel toon reeds duidelik aan dat Calvyn die verhouding van Ou en Nuwe Testament sien van uit die gesigshoek van die verbond.

Calvyn sien die verhouding tussen God en sy volk Israel as 'n verbondsverhouding. Calvyn gebruik vir verbond meesal die woord foedus, hoewel hy dit soms ook weergee met pactio, pactum of testamentum.

Die woord verbond dui aan dat daar 'n vaste, bestendige gemeenskap tussen God en sy volk is. Met nadruk vermeld Calvyn dat hierdie verbond in Christus gegee is, omdat in die versoening wat Christus bewerk het die gemeenskap tussen God en sy volk alleen gerealiseer kan word (Komm. op Gen. $12: 3$ ).

By Calvyn is die verbond sowel in die Ou as in die Nuwe Testament die genadige heilsrelasie tussen God en sy volk. Wolf spreek dan ook geheel tereg van die eenheid van die verbond by Calvyn (1958: 19 e.v.). Die diepste fundering van die eenheid word by Calvyn gevind in sy oortuiging dat die verbond, ook die verbond in sy Ou-Testamentiese vorm 'n eenheid in Christus is (vgl. Calvyn se Komm. op Jes. 42:6: Respondeo, foedus quod percussum tuerat cum Abrahamo et posteris, fundementum fuisse in Christo) (Wolf, 1958:24). In sy kommentaar op Gen. 15:6 trek Calvyn 'n parallel met Rom. 4:3 en dan skrywe hy dat Abraham ten volle in die regverdiging deur die geloof gedeel het en daarin gelyk staan met die gelowiges van die nuwe bedeling.

Die verbond met die vaders, so skrywe Calvyn, is 'in substantia et re' dieselfde as sy verbond met ons (Wolf, 1958:23). Die verskil lê in die wyse van bediening. Calvyn gebruik dan die woorde administratio, oeconomia en dispensatio (Inst. II, X1, 1).

Die diepste rede van die onderskeid tussen die Ou Verbond en die Nuwe Verbond moet volgens Calvyn gesoek word in God se pedagogiese beleid. God openbaar en realiseer nie alles tegelyk nie. Daar is sprake van voorbereiding, opvoeding. Daar is by die Here ' $n$ opvoedkundige motief aanwesig (Graafland, 1978:41).

Calvyn stel dit met nadruk dat die gelowiges in die $\mathrm{Ou}$ Testament onder die wet 'n sodanige vertroulike omgang met God geniet het dat hulle met die volste reg ook lede van die kerk genoem kan word (Inst. II, 11, 10). Volgens die oordeel van Calvyn was die kerk ook reeds in die Ou Testament aanwesig. Wel spreek hy van die kinderlike staat van die kerk in die Ou Testament (status pueritiae ecclesiae). In die Nuwe Testament groei hierdie kinderlike staat van die kerk uit tot volwassenheid (Komm. op Gal. 4:1,2). 
Terwyl die Doperse Beweging die verhouding van Ou en Nuwe Testament aandui as stoflik teenoor geestelik, kom Calvyn met die fyn onderskeiding van jeug teenoor manlike rypheid en volwassenheid.

Calvyn het voldoende oog gehad vir die feit dat die heilsgebeure in Christus in die $\mathrm{Ou}$ Testament 'n toekomstige karakter gehad het, maar dit beteken nie dat die gelowiges daarom geen deel aan die heil wat Christus nog moet verwerf kan hê nie. Inteendeel (Wolf, $1958: 30$ e.v., 37).

God het met Abraham 'n verbond gesluit met die oog op die dood en die opstanding van Christus. Abraham het ook reeds met Christus gesterf en leef met Hom. Die dood en opstanding van Christus is reeds 'n heilswerklikheid alvorens dit in die geskiedenis plaas gevind het. Hierin is Abraham volkome gelyk met alle gelowiges wat na die opstanding van Christus geleef het (Komm. op 2 Tim. 1: 10: Want daarom het Abel, Noag, Abraham, Moses, Dawid en alle godsaliges een en dieselfde saligheid met ons verkry, omdat hulle hulle vertroue in hierdie verskyning ( $\mathrm{nl}$. van Christus gestel het). Wat Calvyn van die gelowiges in die Ou Testament sê geld nie alleen openbaringshistories van hulle nie, maar ook heilsordelik.

Heilsordelik, in die subjektiewe bewuste geloofsbelewing het die gelowiges in die Ou Testament kennis gedra van Christus as hul Verlosser. Calvyn sien 'n bewys hiervan in die offer van Isak. Abraham kon daandie offer bring omdat hy vasgehou het aan die belofte van Christus (Komm. op Gen. 22:2). So het dit nie net met Abraham gegaan nie maar met al die gelowiges in die Ou Testament.

Teenoor die Doperse Beweging wat telkens beweer het dat die gelowiges in die $\mathrm{Ou}$ Testament ' $\mathrm{n}$ laer posisie beklee het, omdat hulle die Heilige Gees nie ontvang het nie, stel Calvyn met groot nadruk dat alle godsvresendes van die begin van die wêreld af begiftig was met dieselfde Gees van verstand, geregtigheid en heiligmaking waarmee die Here vandag sy kinders verlig en vernuwe.

Wel erken Calvyn, en hier beklemtoon hy weer die onderskeid wat daar ook is, dat die kennis van die gelowiges in die Ou Testament duister, swak en omsluierd was in vergelyking met die kennis wat ons vandag van die evangelie besit, maar dit is verklaarbaar, omdat nou Christus, die Son van die geregtigheid gekom het (Komm. op Hand. $2: 17$ ).

Calvyn het dus baie sterk die eenheid van die Ou en Nuwe Testament beklemtoon. In sy prediking het hy dit ook voortdurend verkondig. Daarom kon hy so gemaklik die lyne deurtrek nie alleen van die Ou Testament na die Nuwe Testament nie, maar ook vanuit die Ou Testament na die lewe van die gelowiges in die hede (Graafland, 1978:34).

In ons tyd het verskillende teoloë hulle ook besig gehou met die vraag na die verhouding van die Ou Testament en die Nuwe Testament. Van hulle is D. L. Baker met sy omvattende studie: Two Testaments, One Bible (1976)), G. P. Hasel, Old Testament Theology (1972), P. A. Verhoef, The Relationship between die Old and the New Testaments (1970), F. F. Bruce, This is That (1968) en J. L. 
Helberg, Hoe verklaar en preek ons die Ou Testament, (Klasdiktaat, 1982)?

Dit is met name Helberg wat die twee gesigspunte van Calvyn: die openbaringshistoriese en die heilsordelike deurgetrek en breed uitgewerk het. Hy het daarop gewys dat dit Christus is wat gemaak het dat daar 'n nuwe bedeling en 'n Nuwe Testament kom en dit is Hy wat die Nuwe Testament en die Ou Testament in 'n een-heid verbind. Albei moet van van Hom uit verklaar word, veral vanuit Sy dood en opstanding (1982: 105).

Die Ou Testament sê dat God sy heerskappy oor en die gemeenskap met die mens deurvoer. Ondank die mens se dodelike sondigheid en die goddelike straf daarop. En die Nuwe Testament sê dat dit gebeur op grond van Jesus Christus se soenverdienste en opstanding (Helberg, $1982: 59$ ).

Hierdie heerskappy van God oor die mens en die gemeenskap met God dra volgens Helberg 'n persoonlike, intieme karakter, dit regeer die mens van binne uit, dit raak en roer sy hart, sy wese, sy siel $(1976: 34)$.

God se gemeenskap is ' $n$ persoonlike gemeenskap. Dit beteken dat God Hom aan indiwiduele persone verbind het en nie bloot aan mensegroepe nie. Die Here noem Homself die God van individuele mense en Hy noem hulle by hul name: Abraham, Isak en Jakob.

Die Ou Testament lê die aksent daarop dat God lewe is. Hy is die lewende God. Die Nuwe Testament lê die aksent daarop dat God liefde is. Dit vorm nie ' $n$ teenstelling met die Ou Testamentiese verkondiging nie, want Jesus Christus het juis bewys dat God lewe is, en lewe gee. Maar Hy het ook bewys hoe God dit doen, naamlik deur lewe uit die dood te wek (Helberg, 1976:42). Hierdie lewe is lewe uit die dood wat deur middel van 'n persoonlike geloof ontvang word en wat in 'n persoonlike gemeenskap met God geniet word (Helberg, $1976: 43$ ).

\section{Moderne Doperse tendense}

In die middel van die 20ste eeu het Karl Barth plotseling met 'n skerp afwysing van die kinderdoop gekom. Terwyl die tweede wêreldoorlog in al sy heftigheid gewoed het, het Barth die eerste keer met sy bestryding van die kinderdoop gekom. In sy Kirchliche Dogmatik gee Barth sy sogenaamde 'Fragment' oor die doop waarin hy die sakramentele karakter daarvan afwys (Barth, 1967:144 e.v.).

Barth noem die kinderdoop nie 'n egte doop nie maar ' $n$ verduisterde doop. Tog is hy van oordeel dat die doop van suigelinge, soos hy dit noem, wanneer dit eenmaal plaasgevind het, nie herhaal moet of mag word nie (Barth, 1943; 28-29). Karl Barth is beslis nie 'n wederdoper, 'n anabaptis nie.

Barth se verwerping van die kinderdoop kan gedeeltelik uit sy skerp kritiek op die dooppraktyk in 'n volkskerk verklaar word. Hy het sterk kritiek op die motief agter die ontwikkeling van die kinderdoop. Alhoewel die kinderdoop volgens Barth waarskynlik reeds vroeg in die geskiedenis van die kerk voorgekom het, het dit tog eers algemene praktyk geword in die tyd toe die kerk onder kei- 
ser Konstantyn een met die volk geword het. Omdat die kerk aan hierdie volkskarakter wou vashou, is na die algemene praktyk van die kinderdoop gegryp om die Christendom teen ondergang te beskerm (Barth, 1967: 185).

'n Tweede kritiek wat Karl Barth op die kinderdoop uitoefen, hou verband met sy siening van die skepping. Hy sien dit wat met die skepping gegee is, as 'n bedreiging vir die soewereiniteit van die genade. Ons kan Barth se kritiek op die kinderdoop nie van sy siening op die verhouding tussen skepping en verlossing losmaak nie. Hiermee hang ten nouste Barth se benadering van die verhouding tussen die Ou Testament en die Nuwe Testament saam. Hy stel die Ou Testament as 'n natuurlike verbond teenoor die Nuwe Testament as 'n geestelike. Wel het Barth nog in 1943 erken dat volgens Kol. $2: 11,12$ die doop in die plek van die besnydenis gekom het, maar hy ontken tegelykertyd dat dit ons die reg gee om klein kindertjies te doop. Die besnydenis het volgens Barth te doen met die natuurlike geboorte (Barth, 1943:31). Eintlik is daar geen prinsipiële verskil tussen die kritiek van Karl Barth en die kritiek van die Doperse Beweging op die kinderdoop nie (Berkouwer, 1947 : 134). Die verskil is alleen dat Barth tog nie vir 'n herdoop, ' $n$ weerdoop pleit nie. Karl Barth is dan ook nie 'n Anabaptis nie. Karl Barth het die Reformatoriese teenstelling: sonde - genade verruil vir die Doperse teenstelling: natuur - genade. Die Doperse Beweging kon hom nooit van hierdie in wese Roomse teenstelling losmaak nie en Karl Barth gaan op hulle spoor weer terug agter die Reformasie (Berkouwer, $1947: 111$ ).

'n Duidelike Doperse tendens is ook te vinde in die werk van die bekende Nuwe Testamentikus, Beasley-Murray, wat 'n voortreflike studie oor die doop in die Nuwe Testament geskryf het, maar wat dit onomwonde stel dat daar 'n wesenlike verskil tussen die Ou en die Nuwe Testament is.

Die voorstanders van die kinderdoop beklemtoon volgens hom eensydig die elemente van eenheid in verbond, evangelie en kerk in die twee bedelings, die $\mathrm{Ou}$ en die Nuwe Verbond, en hulle maak hulle oë toe vir die baie duidelike elemente van verskil tussen die twee bedelings (Beasley-Murray, $1979^{3}: 337$ ). By hulle wat die nadruk op die eenheid tussen die twee Testamente lê, word die betekenis van die kruis en die opstanding van Christus en die koms van die Heilige Gees nie reg verstaan nie (Beasley-Murray, 1979³ 338).

Hoe sien Beasley-Murray dan self die verhouding tussen $\mathrm{Ou}$ en Nuwe Testament? Volgens sy oortuiging is die Ou Verbond die bedeling van veroordeling en die dood, terwyl die Nuwe Verbond die bedeling van vergifnis, regverdiging en lewe is (Beasley-Murray, $1979^{3}: 338$ ). Die besnydenis kan daarom nie 'n teken en seël van sondevergewing, regverdiging, hartsvernuwing of heiliging wees nie. Dit is maar net 'n teken dat die kind in Israel tot die verbondsvolk behoort, maar dit het niks met morele vernuwing te doen nie (Beasley-Murray, $1979^{3}: 340,341$ ).

Tereg maak Beasley-Murray onderskeid tussen die besnydenis van die vlees en die besnydenis van die hart, maar volgens hom is 
die besnydenis van die hart soos deur die profete verkondig 'n belofte wat eers in die Nuwe Testament vervul word (Beasley-Murray, $\left.1979^{3}: 341\right)$. Wel erken Beasley-Murray in 'n voetnoot dat die besnydenis van die proseliete 'n meer geestelike betekenis gehad het en dat dit wel in verband gebring is met 'n nuwe geboorte, maar hy sien daarin 'n uitbreiding van die betekenis van die besnydenis, maar vir die Joodse kind het die besnydenis hierdie geestelike betekenis nooit gehad nie (Beasley-Murray, $1979^{3}: 342$ noot 2).

In die diskussie oor die kinderdoop gaan dit in wese oor die verhouding tussen die $\mathrm{Ou}$ en die Nuwe Testament. Een van twee is waar: of die handhawers van die kinderdoop oorskat die betekenis van die Ou Testament en hulle maak geestelik wat net natuurlik is, óf die teenstanders van die kinderdoop onderskat die Ou Testament en hulle beskou as natuurlik wat ook geestelik is. Dit gaan dus in die stryd oor die kinderdoop oor die regte waandering van die Ou Testament.

Moet ons soos Calvyn en die Reformatoriese tradisie uitgaan van die eenheid tussen die twee Testamente, of moet ons Barth, Beasley-Murray en die Anabaptiste uitgaan van 'n totale teenstelling tussen Ou en Nuwe Testament?

\section{Die verbondsstruktuur van die evangelie}

Wanneer daar 'n teenstelling tussen die Ou en die Nuwe Testament is, wanneer beweer word dat daar in die Ou Testament nog geen besnydenis is van die hart plaas gevind het nie dan impliseer dit dat daar in die Ou Testament nog geen ware geloof by die kinders van God wat in Sy verbond opgeneem is te vinde was nie. Hulle bekering kan dan nie as 'n egte, waaragtige bekering beskou word nie.

Waar die Hebreërbrief in die elfde hoofstuk so indringend oor die geloof van die mense van die ou tyd praat, moet dit ' $n$ ander tipe geloof wees en het daardie geloofshelde op 'n manier salig geword as manne soos Petrus en Paulus in die Nuwe Testament. Dan is daar twee soorte gelowe: een vir die mense van die Ou Verbond en 'n ander een vir die mense van die Nuwe Verbond.

Op die vraag na die intrinsieke waarde van die Ou Testament moet dan geantwoord word dat die Ou Testament in vergelyking met die Nuwe Testament as minderwaardig beskou moet wond.

In verband met hierdie probleem is die tweede vraag wat aan die begin gestel is so uiters belangrik: hoe funksioneer die Ou Testament in die Nuwe Testament?

Calvyn gee hierop ' $n$ duidelike antwoord. God se heil in Jesus Christus is volgens Paulus in Rom. 4 'n heil wat net deur geloof ons deel word. Teenoor sy lesers wys Paulus dan daarop dat hierdie heil reeds in die $\mathrm{Ou}$ Testament teruggevind word. Met twee voorbeelde word dit dan aangetoon. Paulus wys op Abraham (Rom. 4:3) en op Dawid (Rom. 4:6). Die geregtigheid wat Abraham ontvang is dieselfde geregtigheid wat aan die gemeente van die Nuwe Verbond geskenk word (Calvyn, Komm. op Rom. $4: 3$ ).

En Dawid ontvang vergewing, omdat hy met die geregtigheid van Christus beklee is (Calvyn, Komm. op Rom. $4: 6-8$ ). 
In Rom. 4 word ook deur Paulus die eenheid tussen die Ou Verbond en die Nuwe Verbond op 'n ondubbelsinnige wyse benadruk, wanneer Paulus spreek oor die vaderskap van Abraham. Uit Rom. $4: 11,12$ blyk dit duidelik dat Abraham die vader van twee groepe mense was: Hy is die vader van almal wat glo terwyl hulle nog onbesnede was. Maar hy is ook die vader van diegene wat nie alleen uit die besny:denis is nie maar wat ook in die voetstappe van Abraham se geloof wandel. Abraham is dus die vader van die gelowiges uit Israel, maar hy is ook die vader van die gelowiges uit die heidene (Botha, 1982:24), "Daar is dus in die hede twee soorte ware Abraham-kinders: die een groep is ware Abrahamkinders, omdat hulle deur Gods genade gelowige vleeslike kinders is van Abraham met wie en met wie se nageslag God sy verbond gesluit het; die ander groep is ware Abrahamkinders, omdat hulle deur Gods genade gelowige geesteskinders van Abraham is op grond van God se verbondsbelofte aan Abraham dat hy die vader van "baie nasies" sal word" (Coetzee, $1965: 174$ ).

Ons moet wel onthou dat die Abrahamkindskap van die heidennasies by Paulus nie indentiek is met die Abrahamkindskap van die volk Israel nie. Dit hou nie 'n vergeesteliking van Israel se kindskap of van Israel self nie. Dit beteken ook nie dat die heidennasies ingelyf is in 'n Israel wat tot 'n geestelike Israel omgeskep is nie. Die geestelike Abrahamkindskap van die heidennasies is vir Paulus gegrond in die verbondsbelofte van God in soverre dit die nasies raak en nie in 'n vergeesteliking van die verbond met Israel nie (Coetzee, $1965: 220,221$ ). Die eenheid tussen die Ou Verbond en die Nuwe Verbond word hier deur Paulus op 'n kernagtige wyse tot uitdrukking gebring. Dit gaan in wese sowel in die Ou Testament as in die Nuwe Testament om dieselfde geloof en dieselfde verbond. In Gal. 3 word ook deur Paulus die eenheid tussen die Ou Verbond en die Nuwe Verbond ter sprake gebring. Paulus wys daarop dat Abraham in God geglo het en dit is hom tot geregtigheid gereken (vs. 6).

In Gal. 3:7, 9 lees ons dan die uitdrukking: die wat glo. Daarmee bedoel Paulus die heidene wat glo. Twee dinge word dan van die gelowiges uit die heidene gesê, hulle is kinders van Abraham (vs. 7) en hulle word saam met die gelowige Abraham geseën (vs. 9). Die seën wat die gelowiges uit die heidene ontvang, word in Gal. $3: 14$ die seën van Abraham genoem en dit is volgens Gal. $3: 6,11,13$ die regverdiging deur die geloof. Die Skrif kom met die goeie nuus dat die heidene op dieselfde wyse as Abraham gered sal word as hulle glo (König, $1979: 28$ ).

'n Derde voorbeeld waarin Paulus die eenheid tussen die $\mathrm{Ou}$ Verbond en die Nuwe Verbond na vore bring is 1 Kor. $10: 1,2$. In hierdie gedeelte skrywe die apostel oor die doop van die volk Israel in Moses in die wolk en in die see. Die gedagte van 'n woestyndoop vind ons ook in die literatuur van die rabbyne terug.

Paulus rig hom in hierdie brief tot Christene wat vir die merendeel uit die heidendom afkomstig was. Tog skrywe hy in 1 Kor. $10: 1$ : Broeders, julle weet dat óns vaders almal onder die wolk was en almal deur die see deurgegaan het.

Met hierdie vaders bedoel hy die vroeë generasie van die 
Joodse volk wat na die verdrukking in Egipte uit die slawehuis uitgelei is.

Soos Abraham die vader van alle gelowiges is, so is die Israeliete die vaders van die Christene in Korinthe. Paulus wys hier op die eenheid wat daar bestaan tussen die Godsvolk van die Ou Testament en die Nuwe Godsvolk waaraan ook die gelowiges uit die heidene toegevoeg is.

Die kerk van die Nuwe Testament is die voortsitting en die vervulling van die historiese volk van God uit die Ou Testament. J. C. Coetzee spreek in hierdie verband van 'n openbaringshistoriese kontinuïteit (Coetzee, $1965: 304$ ).

Uit 1 Kor. 10:1 kan ons duidelik aflei dat Paulus die eenheid van die kerk van alle tye geleer het en dat dit ontoelaatbaar is om 'n skeiding te mak tussen die gelowiges in die ou bedeling en die gelowiges in die nuwe bedeling.

In die Ou Testament het God met Abraham 'n verbond gesluit. God skenk aan Abraham sy genade en $\mathrm{Hy}$ eis van hom en sy nageslag onvoorwaardelike gehoorsaamheid. Die inhoud van God se verbond is: Ek sal vir jou 'n God wees (Gen. 17:7).

Hierdie heerlike versekering van die God-wees van God geld ook vir Abraham se nageslag: En Ek sal vir hulle 'n God wees (Gen. $17: 8$ ). Die enkelvoud: jou word meervoud: hulle. Die Here stel dan die besnydenis in as teken van sy verbond met Abraham en sy nageslag. Dit moet by die kinders op die agste dag ná die geboorte gebeur en geld vir alle lede van Abraham se huishouding, ook vir sy slawe (Gen. $17: 12$ ). Niemand mag hiervan uitgesluit word nie. Daar is geen moontlikheid om onbetrokke te bly teenoor God se beloftes van genade, sy eis om gehoorsaamheid en sy oordeel oor verbondsoortreding nie.

In Matth. 28:19 is dit weer dieselfde God wat Hom aan mense verbind. Inhoud van die verbond of die koninkryk soos dit in konteks van Mattheüs genoem word, is weer dieselfde: Ek sal vir jou 'n God wees en vir jou nageslag ná jou. Maar in die Nuwe Testament openbaar God Hom voller en ryker. Hy, die God van die verbond is die drie-enige God, Vader, Seun en Heilige Gees. Want Jesus sê vir sy dissipels: Ek doop hulle in die naam van die Vader en die Seun en die Heilige Gees.

Die struktuur van die evangelie is duidelik 'n verbondsstruktuur. God kom met Sy belofte tot ons en ons kinders. Sowel in die $\mathrm{Ou}$ Testament as in die Nuwe Testament is die kinders ingesluit. Die belofte van die verbond is vir julle en julle kinders (Hand. $2: 29$ ).

'n Verkeerde siening op die verhouding Ou Testament en Nuwe Testament word dikwels veroorsaak deur 'n diep-gewortelde geloofsindividualisme in die geloofsbelewing wat so kenmerkend was vir die Metodisme en wat ons ook opmerk by die Pentekostalisme en in de Charismatiese Beweging. Die betekenis van die verbond soos die Bybel dit leer word dan nie raak gesien nie.

Dikwels gaan dit saam met 'n biblisistiese hantering van die Skrif sonder enige besef van die openbaringshistoriese karakter daarvan. Wanneer dit ook nog gepaard gaan met 'n Doperse teenstelling 
wat gemaak word tussen natuur en genade dan word die eenheidsband wat die Nuwe Testament aan die Ou Testament bind gemaklik verbreek.

Dit is daarom van die grootste belang dat daar opnuut erns gemaak word met die verbond van God soos dit in die Ou Testament en in die Nuwe Testament geleer word.

Wie vashou aan die verbond van God in sy openbaringshistoriese karakter sal ook die regte verhouding wat daar is tussen die $\mathrm{Ou}$ Testament en die Nuwe Testament raaksien. Ons moet natuurlik wel oppas om nie eensydig op die openbaringshistoriese karakter van die verbond die nadruk laat val nie. Die heilsordelike aspek van die verbond moet ook sy regmatige plek kry in prediking, kategese en pastoraat. Reeds in die Ou Testament word daar kernagtig gewys op heil en heilservaring.

Die Reformasie het ook nooit die betekenis van die ervaring ontken nie. In die Gereformeerde belydenisskrifte kom talle uitdrukkings voor wat ook betrekking het op ervaring. Die ware geloof sal altyd ervaring meebring, maar dit kan nooit die plek van die geloof inneem nie (Jonker, $1981: 238$ ).

Die verskil tussen die kerk en die Doperse Beweging lê nie in die vraag of daar ruimte is vir godsdienstige ervaring of be vinding nie, maar in die vraag na die betekenis wat daaraan toegeskryf word.

Wanneer die eenheid tussen $\mathrm{Ou}$ en Nuwe Testament nie raakgesien word nie en wanneer die verbondsstruktuur van die evangelie ingeruil word vir ' $n$ indiwidualistiese geloofsbelewing dan is die gevaar groot dat die aandag van die Woord weggetrek word en dat dit gevestig word op die mens en sy subjektiewe ervaring.

Dan kry ons nie ervaring as vrug van die geloof nie maar ervaring in die plek van geloof.

Gelewer voor GTV Potchefstroom April 1983

\section{BIBLIOGRAFIE}

Balke, W. Calvijn en de doperse radikalen, 1973.

Barth, K., Die Kirshliche Lehre von der Faufe, 1943.

Barth, K., Kirchliche Dogmatik IV, 4, 1967.

Beasley-Murray, G. R., Baptism in the New Testament, 1979.3

Berkouwer, G C., Karl Barth en de kinderdoop, 1947.

Botha, J., Die kinderdoop, ongepubliseerde Th.B. II-skripsie, PU vir CHO 1982. Bruce, F. F. This is That, 1968.

Coetzee, J. C., Volk en Godsvolk in die Nuwe Testament, 1965.

Den Heyer, C. J., Het Ontstaan en de Ontwikkeling van het Nieuwe Testament, in: Klyn, A. F. J., Inleiding tot de studie van het Nieuwe Testament, 1982.

Floor, L., Eksegese en prediking by Paulus, in: Uw knecht hoort, feestbundel aangeboden aan Prof. W. Kremer, Prof. Dr. J. van Genderen en Prof. Dr. B. J. Oosterhoff, 1979. 
Floor, L., Die Heilige Doop in die Nuwe Testament, 1983.

Graafland, C., Het vaste verbond, 1978.

Hasel, C. F., Old Testament Theology, 1972.

Helberg, J. L., Hoe verklaar ons die Ou Testament?, Klasdiktaat PU vir CHO, 1979.

Heiberg, J. L, Hoe verklaar en preek ons die Ou Testament?, Klasdiktaat PU vir CHO, 1982.

Helberg, J. L., Ou Testamentiese teologie in verleentheid?, 1976.

Jonker, W. D., Die Gees van Christus, 1981.

Koopmans, J., De Nederlandse Geloofsbelijdenis, 1939.

König, A., Strydgesprek oor die Kinderdoop. No. 1 König-Labuschagne, 1979.

Labuschagne, C. J., De verhouding tussen het Oude en het Nieuwe Testament, in: Rondom het Woord Vol. $15 \mathrm{nr} .1,1973$.

Moody Smith, D., The use of the OT in the New, in: The Use of the Old Testament in the New and other essays, Studies in honor of W. F. Stinespring, 1972.

Noordegraaf, A., Schriftgezag en Schriftgebruik in de Handelingen der Apostelen; in Terlouw A., Het hoge Woord, 1976.

Stipperich, B., Die Schriften Bernhard Rothamanns, 1970.

Verhoef, P. A., The Relationship between the Old and New Testament, in: Payne, J. B., Perspectives on the Old Testament, 1970.

Wolf. H. H., Die Einheit des Bundes. Das Verhältnis von Altem und Neuen Testament bei Calvin, 1958.

Quispel, G., Gnosis als Weltreligion, 1972. 